Sains Malaysiana 49(12)(2020): 2951-2961

http://dx.doi.org/10.17576/jsm-2020-4912-07

\title{
Physicochemical Characteristic of Tea Infusion Yoghurt Inoculated with Caspian Sea Yoghurt
}

(Ciri Fizikokimia Yogurt Seduhan Teh yang Diinokulasikan dengan Caspian Sea Yoghurt)

\author{
Shinta Maharani*, Nanda Anggita Sari, Anita Rahayu, M Iqbal Prawira-Atmaja \& Ana A
}

\begin{abstract}
Application inoculum from Caspian Sea Yoghurt to produce yoghurt containing tea infusion have not been developed thoroughly, until recently. This study aimed to determine the physicochemical characteristic and sensory evaluation of tea infusion yoghurt inoculated with Caspian Sea Yoghurt. Green, white, and black tea infusion were added to UHT milk inoculated with Caspian Sea Yoghurt inoculum and incubated at $30^{\circ} \mathrm{C}$ for $12 \mathrm{~h}$. The yoghurt was analyzed at 0, 6 , and 12 h of fermentation including $\mathrm{pH}$, acidity, viscosity, colour ( $\left.L, a^{*}, b^{*}\right)$, total polyphenol, and sensory evaluation. The result showed additional tea infusion on manufacturing yoghurt significantly affected on pH, percentage of acidity, viscosity, and colour parameter of yoghurt. During the fermentation process, the prolonged incubation time resulted in increased acidity and viscosity, while simultaneously decreased the $\mathrm{pH}$ value. At the end of the fermentation (at 12 h) of yoghurt with 10\% tea infusion had a lower $\mathrm{pH}$ and a higher percentage of acidity compared to the yoghurt control. Addition of tea infusion on yoghurt has a lower viscosity than yoghurt without tea infusion at the end of the fermentation. Additional tea infusion on yoghurt affected reduced Lightness $\left(L^{*}\right)$ value but increased $a^{*}$ and $b^{*}$ value. The results of the present study indicate that additional tea infusion on yoghurt inoculated with Caspian Sea Yoghurt should be considered not only in terms of physicochemical and sensory during manufacturing and storage but also functional properties to improve human health.
\end{abstract}

Keywords: Caspian Sea Yoghurt; infusion tea; physicochemical characteristic; total polyphenol

\section{ABSTRAK}

Penggunaan inokulum daripada Caspian Sea Yoghurt untuk menghasilkan yogurt yang mengandungi seduhan teh belum dikembangkan secara menyeluruh sehingga baru-baru ini. Kajian ini bertujuan untuk mengetahui ciri-ciri fizikokimia dan penilaian deria yogurt seduhan teh yang diinokulasikan dengan Caspian Sea Yoghurt. Seduhan teh hijau, putih dan hitam ditambahkan ke dalam susu UHT yang diinokulasi dengan inokulum Caspian Sea Yoghurt dan diinkubasi pada suhu $30^{\circ} \mathrm{C}$ selama 12 jam. Yogurt dianalisis pada 0, 6 dan 12 jam fermentasi termasuk pH, keasidan, kelikatan, warna $\left(L, a^{*}, b^{*}\right)$, polifenol total dan penilaian deria. Hasilnya menunjukkan seduhan teh tambahan pada pembuatan yogurt secara signifikan mempengaruhi $\mathrm{pH}$, peratusan keasidan, kelikatan dan parameter warna yogurt. Selama proses fermentasi, waktu inkubasi yang berpanjangan menghasilkan peningkatan keasidan dan kelikatan, sementara secara bersamaan menurunkan nilai pH. Pada akhir fermentasi (pada 12 jam) yogurt seduhan 10\% teh mempunyai $\mathrm{pH}$ yang lebih rendah dan peratusan keasidan yang lebih tinggi dibandingkan dengan kawalan yogurt. Penambahan seduhan teh pada yogurt mempunyai kelikatan yang lebih rendah daripada yogurt tanpa seduhan teh pada akhir fermentasi. Seduhan teh tambahan pada yogurt mempengaruhi penurunan nilai kecerahan ( $\left.L^{*}\right)$ tetapi meningkatkan nilai $a^{*}$ dan $b^{*}$. Hasil kajian ini menunjukkan bahawa seduhan teh tambahan pada yogurt yang diinokulasikan dengan Caspian Sea Yoghurt harus dipertimbangkan bukan hanya daripada segi fizikokimia dan deria semasa pembuatan dan penyimpanan tetapi juga sifat fungsian untuk meningkatkan kesihatan manusia.

Kata kunci: Caspian Sea Yoghurt; jumlah polifenol; seduhan teh; sifat fizikokimia

\section{INTRODUCTION}

Yoghurt is a fermented milk drink that has health effects when consumed regularly. There are many variants of yoghurt with various flavours with the addition of plant or fruit components, so far (Moore et al. 2018). There are various yoghurt fortification products such as chocolate yoghurt (Chatterjee et al. 2018), coffee (Tan \& Korel 2007), moringa leaves (Shokery et al. 2017), the avocado pulp (Atmanaji et al. 2019), banana flour (Batista et al. 2017) and red-fleshed dragon fruit (Maleta \& Kusnadi 2018). 
Tea (Camellia sinensis) is a beverage that contains bioactive compounds with health benefits (Zhang et al. 2019). Catechins are the main bioactive compounds in green tea while in black tea the bioactive compounds are theaflavin and thearubigin (Katergaris et al. 2015; Sing et al. 2015). Tea has been widely used for food, pharmaceutical and cosmetic products (Prawira-Atmaja \& Rohdiana 2018). Tea can be added to yoghurt directly in the form of leaves, extracts or water tea infusion (Muniandy et al. 2017). Development of tea fortified yoghurt enriched tea phytochemicals with health benefits was possible (Ochanda et al. 2015).

Recently, only a few studies have reported the utilization of bacteria isolated from Caspian Sea Yoghurt to produce yoghurt with a tea infusion. Previous studies reported that some lactic acid bacteria can be used as inoculum in fermented tea yoghurt with various temperature variations. Streptococcus thermophiles and Lactobacillus delbrueckii subsp. bulgaricus is used in yoghurt fermentation with the addition of green tea extract at $43{ }^{\circ} \mathrm{C}$ (Shokery et al. 2017). Yoghurt with the addition of infusion Pu-erh tea fermented at $37{ }^{\circ} \mathrm{C}$ using Lactobacillus acidophilus La-5 inoculum, Bifidobacterium animalis ssp. lactis BB-12 and Streptococcus thermophilus (Najgebauer-Lejko 2019). Lactobacillus delbrueckii subsp. bulgaricus 1.1480, L. acidophilus ys2, S. thermophilus ys 14 and Bifidobacterium bifidum 1.1852 were used in yoghurt fermentation at $42{ }^{\circ} \mathrm{C}$ with the addition of bricktea Fuzhuan leaves (Liu 2018). Yoghurt with the addition of green, black, red, and white tea extracts was fermented at $45{ }^{\circ} \mathrm{C}$ with the addition of Lactobacillus acidophilus LA-5, Bifidobacterium animalis subsp. lactis BB-12, and Streptococcus thermophilus TH-4 45 (Glibowski et al. 2019). Information on the previous study on developing yoghurt enriched tea and different types inoculum as shown in Table 1.

TABLE 1. A previous study on developing yoghurt product with tea and different types inoculum

\begin{tabular}{|c|c|c|c|}
\hline No & Inoculums & Type of tea & References \\
\hline 1 & $\begin{array}{l}\text { Lactobacillus delbrueckii subsp. bulgaricus } \\
\text { (LB) and Streptococcus thermophilus (ST) }\end{array}$ & $\begin{array}{l}\text { extract: thyme, mint, rheum, grape } \\
\text { seeds, and green tea }\end{array}$ & (Alwazeer et al. 2020) \\
\hline 2 & $\begin{array}{l}\text { Kombucha inoculum, Lactobacillus } \\
\text { dulbrueekii sub sp. bulgaricus Streptococcus } \\
\text { salivarius sub sp. thermophilus (YC-280) }\end{array}$ & $\begin{array}{c}\text { bergamot tea, camomile tea, green } \\
\text { tea, cardamom tea, moringa tea, and } \\
\text { black tea }\end{array}$ & (Ayah \& Gehan 2018) \\
\hline 3 & $\begin{array}{l}\text { Streptococcus thermophilus and } \\
\text { Lactobacillus bulgaricus }\end{array}$ & green and black tea & (Ünal et al. 2018) \\
\hline 4 & $\begin{array}{l}\text { Streptococcus thermophilus and } \\
\text { Lactobacillus bulgaricus }\end{array}$ & green tea and green coffee powders & (Dönmez et al. 2017) \\
\hline 5 & $\begin{array}{c}\text { DVS ABT-1 culture (Lactobacillus } \\
\text { acidophilus LA-5, Bifidobacterium } \\
\text { animalis subsp. lactis BB-12, Streptococcus } \\
\text { thermophilus } \text { TH-4) }\end{array}$ & $\begin{array}{l}\text { extract: black tea, red tea, green and } \\
\text { white tea }\end{array}$ & (Glibowski et al. 2019) \\
\hline 6 & S. thermophilus and L. bulgaricus & green and black tea infusion & (Jaziri et al. 2009) \\
\hline 7 & Caspian Sea Yoghurt & Red-fleshed dragon fruit & (Maleta \& Kusnadi 2018) \\
\hline
\end{tabular}

There are other types of bacteria isolated from Caspian Sea Yogurt that can be used in yoghurt fermentation. Caspian Sea Yogurt is a Japanese fermented milk product that contains Lactococcus lactis ssp. cremoris and Acetobacter orientalis (Ishida et al. 2005). Lactococcus lactis ssp. cremoris, lactic acid bacteria, are facultatively anaerobic while Acetobacter orientalis, acetic acid bacteria, is aerobic. Both of these 
bacteria can grow at a temperature of $30^{\circ} \mathrm{C}$. Temperature fermentation is one of crucial parameters that affected the growth of lactic acid bacteria and the production of exopolysaccharides during yoghurt production (Vaningelgem et al. 2004). This study aims to determine physicochemical characteristic and sensory evaluation of yoghurt with tea infusion (green, white, and black tea) inoculated with Caspian Sea Yoghurt during $12 \mathrm{~h}$ fermentation.

\section{MATERIALS AND METHODS}

Culture starter of Caspian Sea (Lactococcus lactis subsp. Cremoris FC and Acetobacter orientalis FA) from Fujikko Caspian Sea Yogurt Handmade Inoculum was used for the production of yoghurt. Black tea, green tea, and white tea were obtained from Indonesia Research Institute for Tea and Cinchona (RITC). Other ingredient UHT milk full cream (contained 3,1\% of fat), sugar, packaging material (plastic bottles) were obtained from a local retail shop.

\section{PREPARATION OF TEA INFUSION}

The preparation of black tea and green tea infusion was carried out to the method described by SNI 1902:2016 for black tea (Badan Standarisasi Indonesia 2016) and SNI 3945:2016 for green tea (Badan Standardisasi Nasional 2016). Briefly, $10 \mathrm{~g}$ of tea was added $100 \mathrm{~mL}$ of boiled water and steep for $6 \mathrm{~min}$, and for white tea steeping time for $10 \mathrm{~min}$. The water of tea was filtered and cooled until further uses in manufacturing yoghurt.

\section{PREPARATION OF INOCULUM}

For activation of Caspian Sea Yoghurt starter, $3 \mathrm{~g}$ of inoculum were dissolved in $500 \mathrm{~mL}$ of UHT milk and incubated at $30{ }^{\circ} \mathrm{C}$ for $24 \mathrm{~h}$. Activated cultures were used for yoghurt manufacturing at $10 \%(\mathrm{v} / \mathrm{v})$ containing 6.18 $\times 10^{7} \mathrm{CFU} / \mathrm{mL}$.

\section{MANUFACTURING OF YOGHURT}

Manufacturing of yoghurt was carried out the method describe by Najgebauer-Lejko et al. (2011) with slight modification. Yoghurt was prepared by dissolved $10 \mathrm{~g}$ of sucrose in UHT milk. Tea infusion $10 \%$ and activated culture of Caspian Sea $(10 \% \mathrm{v} / \mathrm{v})$ were transferred into 90 $\mathrm{mL}$ of milk containing sucrose. After completely mixed, it was then incubated at $30 \pm 1^{\circ} \mathrm{C}$ for $12 \mathrm{~h}$ in a jar. Yoghurt sample was analyzed at $0,6,12 \mathrm{~h}$ of fermentation.

\section{MEASUREMENT OF PH AND ACIDITY}

The $\mathrm{pH}$ of yoghurt samples was measured using a $\mathrm{pH}$ meter (Ohaus, Germany) with a glass electrode (SNI
06-6989). Acidity was determined by titration with $0.1 \mathrm{~N}$ $\mathrm{NaOH}$ using phenolphthalein $1 \%$ as an indicator of colour (Izadi et al. 2015).

\section{DETERMINED OF VISCOSITY}

Viscosity was measured using a viscometer model Brookfield Viscometer using a glass tube and a normalized ball equipped with speed $30 \mathrm{rpm}$. Viscosity was expressed as a cP value (Dahlan \& Sani 2017).

\section{COLOUR ANALYSIS}

The colour of yoghurt was measured using chromameter with operation following the instruction of the manufacture. The colour was expressed as L (darkness/ whiteness), a (greenness/redness), and b (blueness/ yellowness) (Glibowski et al. 2019).

\section{DETERMINATION TOTAL POLYPHENOL IN YOGHURT PREPARATION OF EXTRACT YOGHURT}

$10 \mathrm{~g}$ of yoghurt was added with $2.5 \mathrm{~mL}$ of aquadest. Adjust the $\mathrm{pH}$ of the solution at $4 \mathrm{using} 1 \mathrm{~mL} \mathrm{HCl}$. Yoghurt then incubated at $45{ }^{\circ} \mathrm{C}$ for $10 \mathrm{~min}$, centrifuges $(4000$ $\mathrm{rpm}, 20 \mathrm{~min}$ ). After filtered, the supernatant was added $\mathrm{NaOH}$ until reach of $\mathrm{pH}$ neutral and centrifuges for 20 $\min (4000 \mathrm{rpm})$. The supernatant was used to determining total polyphenol.

\section{ANALYSIS OF TOTAL POLYPHENOL}

Total polyphenol was determined using Folin-Ciocalteau method. $1 \mathrm{~mL}$ of homogenized yoghurt was transferred into tube flask. The sample then added with $1 \mathrm{~mL}$ ethanol $95 \%$ and $5 \mathrm{~mL}$ of aquadest to make dilution concentration at $1000 \mathrm{ppm}$. The sample was further reacted with $0.5 \mathrm{~mL}$ of Folin-Ciocalteau's reagent $(50 \%, \mathrm{v} / \mathrm{v})$ for $5 \mathrm{~min}$ to form a blue-coloured solution.

Then, $1 \mathrm{~mL}$ of $\mathrm{Na}_{2} \mathrm{CO}_{3} 5 \%$ to stabilize the colour formed. The blue colour was allowed to develop for at least $2 \mathrm{~h}$ and its absorbance then measured at $725 \mathrm{~nm}$, using UV-vis Spectro. The amount of total polyphenol obtained from the standard curve equation of gallic acid solution with a concentration range of 1-100 ppm.

\section{SENSORY EVALUATION}

Sensory quality of yoghurt products was evaluated by 20 semi-trained panellists with a 7-point hedonic scale and involved the following parameters: aroma, colour, viscosity/texture, and taste. Panellists tested the samples and were asked to keep the yoghurt in the mouth for 12 $\mathrm{s}$ before scoring. The yoghurt samples were presented in random order. Water was used for rinsing mouth between samples. 


\section{STATISTICAL ANALYSIS}

All data were evaluated using descriptive statistic for average \pm standard deviation. One-way analysis of variance (ANOVA) was carried out. Differences between sample assessed on a confident interval using Duncan Multiple Range Test (DMRT) at the level of significance was $p \leq 0.05$ was used to analyse the data.

\section{RESULTS AND DISCUSSION}

\section{PH AND ACIDITY OF YOGHURT}

Acidity and $\mathrm{pH}$ are the main parameters of the yoghurt product. Figure 1 shows the result of $\mathrm{pH}$ and per cent acidity of yoghurt containing water infusion of tea during fermentation 0,6 , and $12 \mathrm{~h}$. During fermentation, all $\mathrm{pH}$ of yoghurt decreased significantly (Figure 1(a)). Addition tea infusion on yoghurt resulted in the lowest $\mathrm{pH}$ value than yoghurt control. Yoghurt with $10 \%$ white tea infusion has the lowest $\mathrm{pH}$ value than yoghurt with $10 \%$ green tea infusion, black tea infusion, and control with a $\mathrm{pH}$ value: $4.45,4.46,4.47$, and 4.49 , respectively. Decreasing in $\mathrm{pH}$ in yoghurt during fermentation is correlation to the increase in the percentage of acid. Decreased $\mathrm{pH}$ value on yoghurt also reported by Najgebauer-Lejko et al. (2011) that addition yoghurt with $10 \%$ of green tea at 12 $\mathrm{h}$ fermentation reached 4.46, lower than control. Duration time of fermentation/incubation also significantly affected $\mathrm{pH}$ value and acidity of yoghurt with the addition of brick-tea Fuzhuan (Krisnaningsih et al. 2019; Liu 2018). a)

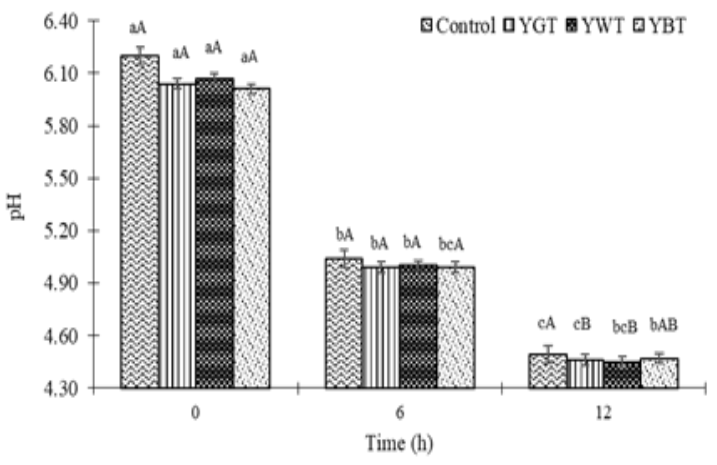

b)

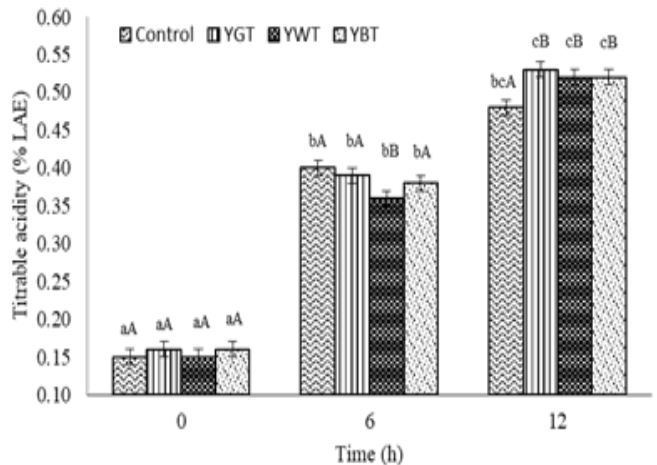

FIGURE 1. Change of a) $\mathrm{pH}$ and b) titrable acidity (\% LAE) of yoghurt contains a different type of tea infusion during $12 \mathrm{~h}$ fermentation. Control: yoghurt plain; YGT: yoghurt with $10 \%$ green tea infusion; YWT: yoghurt with 10\% white tea infusion; and YBT: yoghurt with $10 \%$ black tea infusion

Data are represented as mean $\pm \mathrm{SD}$ (standard deviation) of three replications. Different superscript letters (a-c) indicate significant differences between fermentation time. Different superscript letter (A-C) indicates significant differences between the type of tea infusion tea and control at $\mathrm{P}<0.05$ according to a DMRT

The percentage of acidity is assumed as lactic acid during yoghurt fermentation at a temperature of $30{ }^{\circ} \mathrm{C}$. The acidity of yoghurt increases significantly at $6 \mathrm{~h}$ of fermentation from $0.15-0.17 \%$ at $0 \mathrm{~h}$ to $0.37-0.40 \%$ at $6 \mathrm{~h}$ fermentation. Percent acidity of yoghurt at $12 \mathrm{~h}$ fermentation is $0.48,0.53$, and 0.52 on yoghurt without added tea infusion (control), yoghurt with green, white, and black tea infusion, respectively. A previous study reported by Maharani et al. (2014) that acidity increased during fermentation of black soy yoghurt with inoculum Caspian Sea Yoghurt with per cent acidity of $0.30-0.40 \%$ at $6 \mathrm{~h}$ of fermentation.
Our results show that at the end of the fermentation (at $12 \mathrm{~h}$ ) of yoghurt with $10 \%$ tea infusion had a lower $\mathrm{pH}$ and higher percentage of acidity compared to the yoghurt control. According to Alwazeer at al. (2020), lactic acid bacteria produce higher percentage of acidity in milk with the addition of various plant extracts. During fermentation, the $\mathrm{pH}$ of yoghurt declines in proportion to the increase in the percentage of lactic acid. Lactic acid is formed from the fermentation of milk lactose by lactic acid bacteria (Chen et al. 2017). The acidity in yoghurt with tea infusion increases due to the bioactive compound in tea (Najgebauer-Lejko et al. 2014). The bioactive compound of tea can increase the acidity of 
yoghurt without disturbing the growth of lactic acid bacteria in yoghurt. Tea can stimulate bacterial growth during fermentation and support lactic acid production (Najgebauer-Lejko et al. 2011). The antimicrobial activity in tea only affects the growth of pathogenic bacteria such as E. coli, B. cereus, S. aureus, and C. albicans without disturbing the growth of lactic acid bacteria (Ünal et al. 2018).

\section{VISCOSITY OF YOGHURT}

The viscosity of yoghurt increased significantly during fermentation at 6 and $12 \mathrm{~h}$. Yoghurt control has a higher viscosity than yoghurt with a tea infusion. Addition tea infusion on manufacturing yoghurt affected on decreased of viscosity yoghurt at initial time fermentation and the end of fermentation (Figure 2). It can be seen that the addition of $10 \%$ of tea infusion has lowered viscosity $1535.50-1624.00 \mathrm{cP}$ than yoghurt control with viscosity $1879.75 \mathrm{cP}$ at $12 \mathrm{~h}$ fermentation. The apparent viscosity of yoghurt prepared from cow's milk with Streptococcus thermophilous and Lactobacillus bulgaricus was 173.50 $\mathrm{cP}$ at the end of fermentation (Atmanaji et al. 2019). The highest viscosity of yoghurt is obtained from the lower per cent acidity and higher the $\mathrm{pH}$ value of yoghurt (Krisnaningsih et al. 2019).

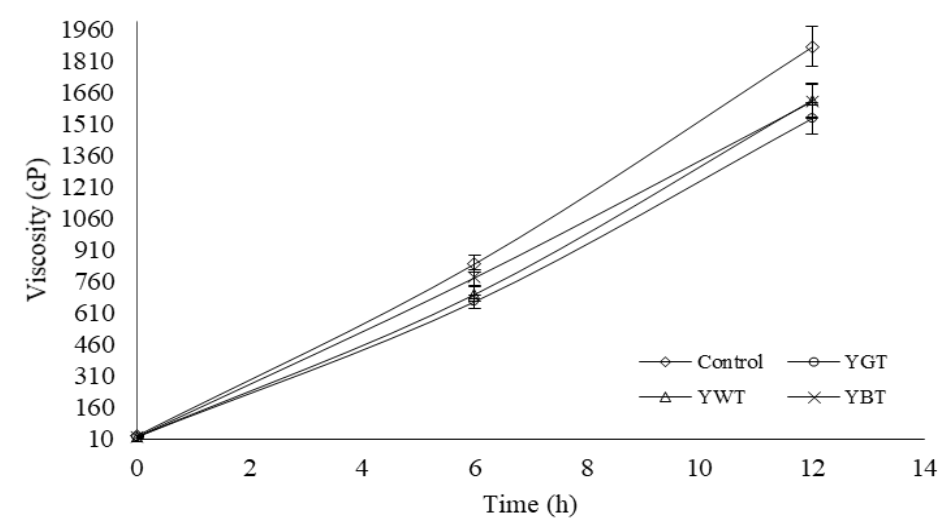

FIGURE 2. Change of viscosity (cP) of yoghurt contain a different type of tea infusion during 12 h fermentation. Control: yoghurt plain; YGT: yoghurt with 10\% green tea infusion; YWT: yoghurt with 10\% white tea infusion; and YBT: yoghurt with $10 \%$ black tea infusion.

Data are represented as mean \pm SD (standard deviation) of three replications. Different superscript letters (a-c) indicate significant differences between fermentation time. Different superscript letter (A-C) indicates significant differences between the type of tea infusion tea and control at $\mathrm{P}<0.05$ according to a DMRT

Addition of tea infusion on yoghurt has a lower viscosity than yoghurt without tea infusion at the end of the fermentation (Ünal et al. 2016). It also reported that addition $4 \%$ of green tea on yoghurt has a lower viscosity than yoghurt with the infusion of black tea. Caspian Sea Yoghurt has a higher viscosity because Lactococcus (L) lactic ssp. cremoris produces exopolysaccharides (EPS) (Uchida et al. 2009). EPS production of starter cultures significantly improved apparent viscosity and sensory attributes of yoghurt (Madhubasani et al. 2020). The duration of fermentation also affected on yoghurt viscosity.

The viscosity of yoghurt is influenced by the number and strength of the bonds between casein micelles in yoghurt. Casein aggregation occurs at isoelectric $\mathrm{pH}$
$<4.9$ with maximum gel stiffness occurring at $\mathrm{pH} 4.6$ (Phadungath 2005). Increasing viscosity is directly proportional to the production of exopolysaccharide by lactic acid bacteria during yoghurt fermentation (Madhubasani et al. 2020). During yoghurt fermentation, the increase in exopolysaccharide corresponds to a decrease in lactose and an increase in lactic acid in yoghurt (Vaningelgem et al. 2004).

Addition of tea infusion can affect the viscosity of yoghurt. Interactions between tea polyphenols and milk protein, at certain concertation, can improve the network structure of casein and the consistency of yoghurt (Dönmez et al. 2017). According to Phadungath (2005), the strength of casein gel in yoghurt is correlation with concentration of casein while according to the 
Najgebauer-Lejko et al. (2014) interaction between protein and polyphenols are influenced by the concentration and ratio of protein and polyphenols, and conditions of $\mathrm{pH}$ and temperature, and the treatment of additional ingredients.

\section{COLOUR OF YOGHURT}

Colour is an important attribute in food that perceived by the consumer and often influences the consumer preference (Sah et al. 2016). Figure 3 shows the colour parameters of yoghurt containing tea infusion on yoghurt control at 0,6 , and $12 \mathrm{~h}$ fermentation. Yoghurt without addition tea infusion has $\mathrm{L}$ (lightness) value higher than yoghurt with addition $10 \%$ tea infusion with
$\mathrm{L}^{*}$ value 91 compared yoghurt with green, white, and black tea infusion with $88.33,89.98$, and 82.20 at $0 \mathrm{~h}$ fermentation, respectively. Addition black tea infusion on yoghurt produces L value lower than green and white tea infusion on yoghurt. Green tea and black tea yoghurt produce the same brightness as yoghurt control at $12 \mathrm{~h}$ of fermentation.

Values of a* indicate red and green colour. Addition black tea infusion produces yoghurt with reddish colour while green and white tea produces yoghurt with a yellowish-green colour. Among the variations of type tea infusion yoghurt, yoghurt with the addition of black tea infusion water gives the highest yellow colour $\left(b^{*}\right)$ at initial fermentation $(0 \mathrm{~h})$ until $12 \mathrm{~h}$.

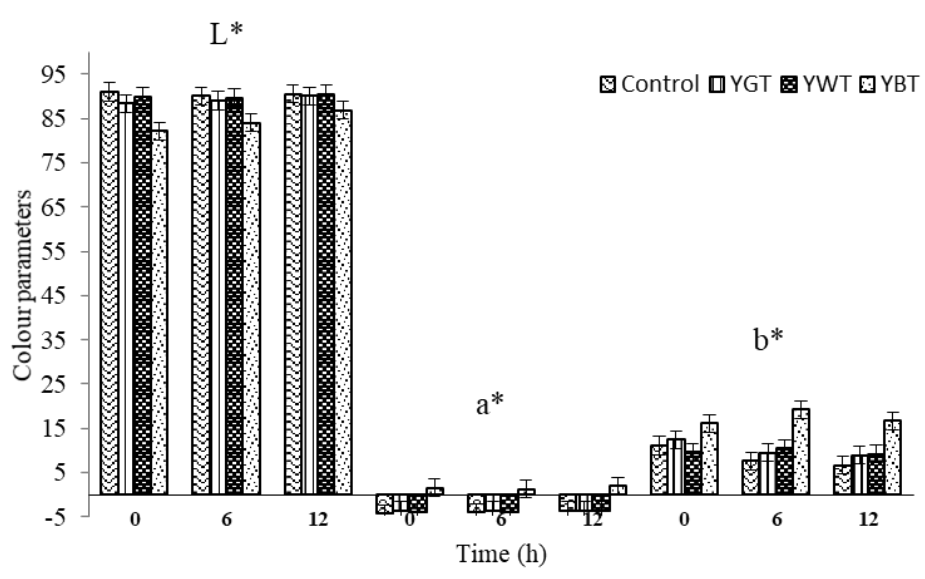

FIGURE 3. Change of colour profile parameters yoghurt contains a different type of tea infusion during $12 \mathrm{~h}$ fermentation. $\mathrm{L}^{*}$ - lightness, $\mathrm{a}^{*}$ - green-red colour, $\mathrm{b}^{*}$ - blue-yellow colour of Control: yoghurt plain; YGT: yoghurt with 10\% green tea infusion; YWT: yoghurt with $10 \%$ white tea infusion; and YBT: yoghurt with $10 \%$ black tea infusion.; means \pm SD

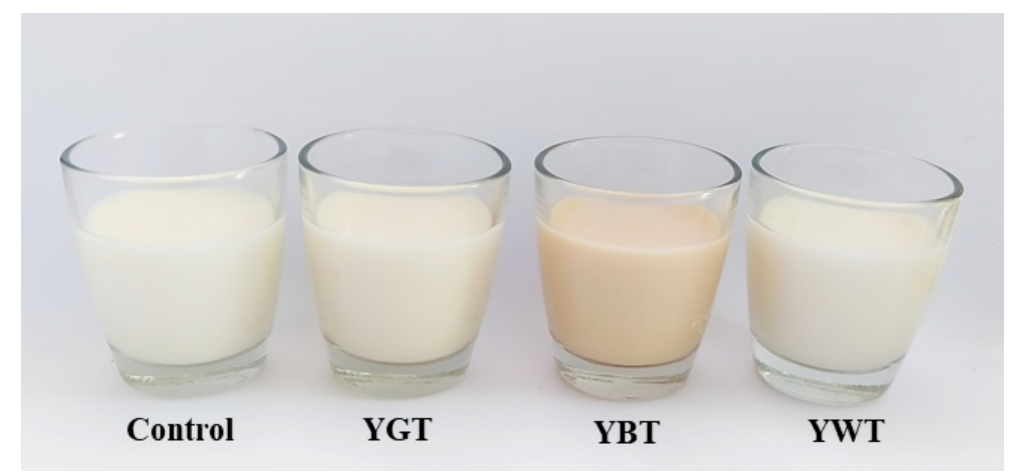

FIGURE 4. Visual assessment of yoghurt contains a different type of tea infusion. Control: yoghurt plain; YGT: yoghurt with 10\% green tea infusion; YWT: yoghurt with $10 \%$ white tea infusion; and YBT: yoghurt with $10 \%$ black tea infusion 
The study results also supported by Glibowski et al. (2019) that yoghurt with the addition of $12 \%$ of black tea infusion produced the darkest colour (62.28) among the green tea yoghurt (71.04) and white tea yoghurt (68.35) thus lowering the colour brightness of yoghurt. Similar things occur in reddish and yellowish colour in yoghurt after $12 \mathrm{~h}$ of fermentation with the addition of $10 \%$ the Pu-er (Najgebauer-Lejko 2019). Our result showed that additional tea infusion on yoghurt reduced Lightness $\left(\mathrm{L}^{*}\right)$ value but increased $\mathrm{a}^{*}$ and $\mathrm{b}^{*}$ value (Figure 4). Reddish value on yoghurt with tea infusion due to the presence of theaflavin and theobrownin while chlorophyll, flavonols, and flavones contribute to the greenish and yellowish-green colour (Donlao \& Ogawa 2019; Najgebauer-Lejko et al. 2014).

\section{TOTAL POLYPHENOL OF YOGHURT}

The total polyphenols analyzed on yoghurt containing tea infusion at $12 \mathrm{~h}$ fermentation. Figure 5 shows total polyphenol content in three types of tea yoghurt. Yoghurt with green tea infusion has the highest total polyphenol when compared with other yoghurts. Total polyphenols contents are $30.42,28.81$, and $13.63 \mathrm{~g} \mathrm{GEA} / \mathrm{g}$ extract on yoghurt with green, black and white tea infusion, respectively.

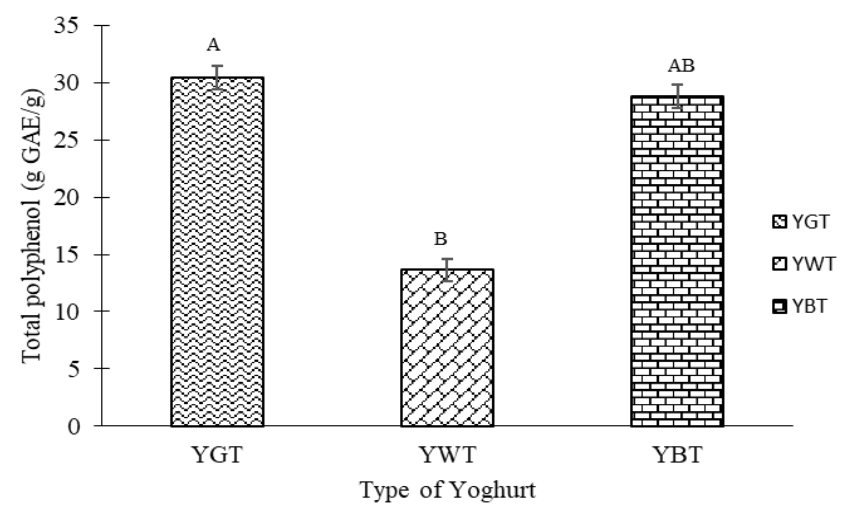

\begin{abstract}
FIGURE 5. Total polyphenol of yoghurt contains a different type of tea infusion after $12 \mathrm{~h}$ fermentation. YGT: yoghurt with 10\% green tea infusion; YWT: yoghurt with $10 \%$ white tea infusion; and YBT: yoghurt with 10\% black tea infusion
\end{abstract}

Data are represented as mean \pm SD (standard deviation) of three replications. Different superscript letter (A-C) indicates significant differences between the type of tea infusion tea and control at $\mathrm{P}<0.05$ according to a DMRT

In our results, it is shown that the total polyphenols in white tea yoghurt lower than black tea yoghurt. According to Muniandy et al. (2016), the total polyphenol of yoghurt with green tea infusion higher than yoghurt with white and black tea infusion. Result study also reported by Almajano et al. (2008) with the total polyphenol in green, white and black tea infusion were 2083, 2180, and $1844 \mu \mathrm{g}$ GAE/L, respectively. The lowest polyphenol content in yoghurt with white tea infusion might be affected by different forms between white (leaf) and black tea (powder), steeping time, water-to-tea ratio and extraction method during preparation of infusion. Particle size in the material is one of the factors that influence the efficiency of the extraction process (Zhang et al. 2018). The observed effects of increasing phenols and antioxidant levels with increasing infusion times were also known to be influenced by stirring duration and intensity, leaf size, and tea bag porosity (Nikniaz et al. 2016). Optimization of tea polyphenol extraction is a complex mechanism and influenced by several factors such as extraction method, steeping time, temperature, tea-to-water ratio, solvent extraction, form and type of tea (Nikniaz et al. 2016).

\section{SENSORY EVALUATION OF YOGHURT}

The sensory evaluation of yoghurt was performed using 20 semi-trained panellists on yoghurt with 12 $\mathrm{h}$ fermentation. The parameters tested by the panellists 
included aroma, colour, texture (viscosity), and taste. The results showed that the level of aroma preference between control yoghurt and yoghurt with the addition of tea was not significantly different statistically with values ranging from 4.55-4.75. Panellists, in colour parameters, tend to accept colour in control yoghurt and yoghurt with the addition of white tea with a score of 5.65 and 5.45, respectively.
Panellists showed little acceptance of the colour of yoghurt with the addition of black tea with a score of 4.35 while for texture or viscosity, panellists tend to accept control yoghurt, green and white tea when compared to yoghurt with black tea. In the taste parameter, yogurt with white tea gets the highest score of 5.16 when compared to other yoghurt products.

TABLE 2. Sensory evaluation of yoghurt contained a different type of tea infusion

\begin{tabular}{lcccc}
\hline & & \multicolumn{3}{c}{ Type of tea infusion } \\
\cline { 3 - 5 } Parameters & Control & Green tea & White tea & Black tea \\
\hline Aroma & $4.63 \pm 0.11^{\mathrm{a}}$ & $4.75 \pm 0.21^{\mathrm{a}}$ & $4.68 \pm 0.32^{\mathrm{a}}$ & $4.55 \pm 0.28^{\mathrm{a}}$ \\
Color & $5.65 \pm 0.07^{\mathrm{a}}$ & $4.85 \pm 0.28^{\mathrm{b}}$ & $5.44 \pm 0.05^{\mathrm{a}}$ & $4.35 \pm 0.64^{\mathrm{c}}$ \\
Texture & $4.73 \pm 0.18^{\mathrm{a}}$ & $4.75 \pm 0.21^{\mathrm{a}}$ & $4.73 \pm 0.25^{\mathrm{a}}$ & $4.60 \pm 0.21^{\mathrm{b}}$ \\
Taste & $4.76 \pm 0.19^{\mathrm{a}}$ & $4.76 \pm 0.11^{\mathrm{a}}$ & $5.16 \pm 0.15^{\mathrm{b}}$ & $4.74 \pm 0.30^{\mathrm{a}}$ \\
\hline
\end{tabular}

Data are represented as mean $\pm \mathrm{SD}$ (standard deviation) of three replications. Different letters in the line indicate significant differences between the type of tea infusion at $\mathrm{P}<0.05$ according to a DMRT

The results study by Glibowski et al. (2019) states that yoghurt with the addition of $4 \%$ of green tea infusion is preferably panellist than yoghurt with the addition of $12 \%$ black tea infusion. Dyes in black tea affect the taste and colour of tea infusion (Liang et al. 2003). The taste of yoghurt is positively correlated to overall yoghurt reception (Dias et al. 2020).

The formation of the aroma of yoghurt comes from the metabolism of lactic acid bacteria such as glycolysis, proteolysis, and lipolysis (Moore et al. 2018). Lactose is hydrolyzed to the glucose monomer and converted into compounds that contribute to yoghurt flavours such as lactate, acetaldehyde, ethanol, and diacetyl. Free amino acids produced by proteolysis may be converted to various flavour compounds including ammonia, amines, aldehydes, phenols, indole, and alcohols. The principal cyclic compounds in yoghurt are $\gamma$ - and $\delta$-lactones, which have 5 and 6-sided rings, respectively, and are stable and strongly fruity flavoured from lipolysis (Chen et al. 2017). Tea infusion also contributes to the aroma of yoghurt because tea contains high volatile compounds such as alcohols, aldehydes, and lactones, that originate from saturated and unsaturated fatty acids (Yang et al. 2013).
The taste of yoghurt is influenced by the formation of lactic acid during fermentation (Chen et al. 2017). Uchiyama et al. (2011) found that the astringency and umami level decreased, whereas the bitterness level increased during tea fermentation. Furthermore, other tea components such as thearubigins and theaflavins are also reported to affect the sensory characteristics of the tea especially the brightness of tea colour (Owuor \& Obanda 2001). Caffeine is regarded as an important parameter for commercial tea sensory evaluation having a significant contribution to the development of taste. The quality of tea is strongly associated with the amount of caffeine content for the formation of flavoured precipitates during the infusion process (Smith et al. 1994). The chemicals responsible for the taste and appearance of black tea are the theaflavins and thearubigins. Theaflavins are responsible for the astringency, brightness, colour and briskness of the black tea, while thearubigins contribute to the mouthfeel (thickness) and colour of the tea (Biswas et al. 1973).

\section{CONCLUSION}

Additional tea infusion on manufacturing yoghurt significantly affected on $\mathrm{pH}$, percentage of acidity, 
viscosity, and colour parameter of yoghurt. Our result study showed that at the end of the fermentation (at $12 \mathrm{~h}$ ) of yoghurt with $10 \%$ tea infusion had a lower $\mathrm{pH}$ and higher percentage of acidity compared to the yoghurt control. Yoghurt viscosity increases with increasing fermentation time. Addition of tea infusion on yoghurt has a lower viscosity than yoghurt without tea infusion at the end of the fermentation. Additional tea infusion on yoghurt affected reduced Lightness ( $\mathrm{L}^{*}$ ) value but increased $a^{*}$ and $b^{*}$ value. Sensory evaluation showed that all variation yoghurts was accepted by panellists. The results of the present study indicate that additional tea infusion on yoghurt inoculated with Caspian Sea Yoghurt should be considered not only in terms of physicochemical and sensory during storage but also in respect of the improved health-promoting properties attributed to yoghurt tea constituents.

\section{ACKNOWLEDGEMENTS}

This work was supported by Lembaga Penelitian dan Pengabdian Masyarakat (LPPM) Universitas Pendidikan Indonesia Tahun 2019 (No. 5156/UN40.A5/ PT.01.03/2019).

\section{REFERENCES}

Almajano, M.P., Carbó, R., Jiménez, J.A.L. \& Gordon, M.H. 2008. Antioxidant and antimicrobial activities of tea infusions. Food Chemistry 108(1): 55-63.

Alwazeer, D., Bulut, M. \& Tunçtürk, Y. 2020. Fortification of milk with plant extracts modifies the acidification and reducing capacities of yoghurt bacteria. International Journal of Dairy Technology 73(1): 117-125.

Atmanaji, B.S.H. \& Pramono, A. 2019. Physical and hedonic properties of cow milk yogurt containing different levels of avocado pulp (Perseaamericana, Mill). In IOP Conference Series: Materials Science and Engineering. Kuala Lumpur: Sigma Research and Consulting Sdn. Bhd. pp. 012049 .

Ayah, B.A.S. \& Gehan, F.G. 2018. Biological activity and physicochemical quality of different types of Kombucha yoghurt vs traditional yoghurt during storage. Bioscience Research 15(3): 2816-2827.

Badan Standardisasi Nasional. 2016. SNI 3945:2016. Teh Hijau. Jakarta: Badan Standardisasi Nasional.

Badan Standarisasi Indonesia. 2016. SNI 1902:2016. Teh Hitam. Jakarta: adan Standardisasi Nasional.

Batista, A.L.D., Silva, R., Cappato, L.P., Ferreira, M.V.S., Nascimento, K.O., Schmiele, M., Esmerino, E.A., Balthazar, C.F., Silva, H.L.A., Moraes, J., Pimentel, T.C., Freitas, M.Q., Raices, R.S.L., Silva, M.C. \& Cruz, A.G. 2017. Developing a synbiotic fermented milk using probiotic bacteria and organic green banana flour. Journal of Functional Foods 38 (Part A): 242-250.

Biswas, A.K., Sarkar, A.R. \& Biswas, A.K. 1973. Biological and chemical factors affecting the valuation of north east Indian plains teas. III. Statistical evaluation of the biochemical constituents and their effects on colour, brightness and strength of black teas. Journal of the Science of Food and Agriculture 24(12): 1457-1477.

Chatterjee, G., Das, S., Das, R.S. \& Des, A.B. 2018. Development of green tea infused chocolate yoghurt and evaluation of its nutritive value and storage stability. Progress in Nutrition 20(Supplement 1): 237-245.

Chen, C., Zhao, S., Hao, G., Yu, H., Tian, H. \& Zhao, G. 2017. Role of lactic acid bacteria on the yogurt flavour: A review. International Journal of Food Properties 20(1): S316-S330.

Dahlan, H.A. \& Sani, N.A. 2017. The Interaction effect of mixing starter cultures on homemade natural yogurt's $\mathrm{pH}$ and viscosity. International Journal of Food Studies 6(2): 152-158.

Dias, P.G.I., Sajiwani, J.W.A. \& Rathnayaka, R.M.U.S.K. 2020. Consumer perception and sensory profile of probiotic yogurt with added sugar and reduced milk fat. Heliyon 6(7): e04328.

Donlao, N. \& Ogawa, Y. 2019. The influence of processing conditions on catechin, caffeine and chlorophyll contents of green tea (Camelia sinensis) leaves and infusions. Lwt 116: 108567.

Dönmez, Ö., Mogol, B.A. \& Gökmen, V. 2017. Syneresis and rheological behaviors of set yogurt containing green tea and green coffee powders. Journal of Dairy Science 100(2): 901-907.

Glibowski, P., Karwowska, M., Latoch, A., Nosowska, K. \& Udeh, K.O. 2019. Effect of different tea extracts on the physicochemical and sensory parameters of stirred probiotic yoghurts. Acta Scientiarum Polonorum, Technologia Alimentaria 18(2): 185-193.

Ishida, T., Yokota, A., Umezawa, Y., Toda, T. \& Yamada, K. 2005. Identification and characterization of lactococcal and acetobacter strains isolated from traditional caucasusian fermented milk. Journal of Nutritional Science and Vitaminology 51(3): 187-193.

Izadi, Z., Nasirpour, A., Garoosi, G.A. \& Tamjidi, F. 2015. Rheological and physical properties of yogurt enriched with phytosterol during storage. Journal of Food Science and Technology 52(8): 5341-5346.

Jaziri, I., Slama, M.B., Mhadhbi, H., Urdaci, M.C. \& Hamdi, M. 2009. Effect of green and black teas (Camellia sinensis L.) on the characteristic microflora of yogurt during fermentation and refrigerated storage. Food Chemistry 112(3): 614620.

Katergaris, N., Dufficy, L., Roach, P.D. \& Naumovski, N. 2015. Green tea catechins as neuroprotective agents: Systematic review of the literature in animal pre-clinical trials. Advances in Food Technology and Nutritional Sciencies Open Journal 1(2): 48-57.

Krisnaningsih, A.T., Purwadi, L.E.R., Evanuarini, H. \& Rosyidi, D. 2019. The effect of incubation time to the physicochemical and microbial properties of yoghurt with local taro (Colocasia esculenta (L.) schott) starch as stabilizer. Current Research in Nutrition and Food Science 7(2): 547-554. 
Liang, Y., Lu, J., Zhang, L., Wu, S. \& Wu, Y. 2003. Estimation of black tea quality by analysis of chemical composition and colour difference of tea infusions. Food Chemistry 80(2): 283-290.

Liu, D. 2018. Effect of Fuzhuan brick-tea addition on the quality and antioxidant activity of skimmed set-type yoghurt. International Journal of Dairy Technology 71(S1): 22-33.

Madhubasani, G.B.L., Prasanna, P.H.P., Chandrasekara, A., Gunasekara, D.C.S., Senadeera, P., Chandramali, D.V.P. \& Vidanarachchi, J.K. 2020. Exopolysaccharide producing starter cultures positively influence on microbiological, physicochemical, and sensory properties of probiotic goats' milk set-yoghurt. Journal of Food Processing and Preservation 44(3): e14361.

Maharani, S., Utami, T. \& Cahyanto, M.N. 2014. Pengaruh suhu dan jumlah inokulum terhadap perubahan kimia, fisik dan mikrobiologis yogurt susu kedelai hitam dengan inokulum Caspian Sea yogurt. Universitas Gadjah Mada. M.Sc. (Unpublished).

Maleta, H.S. \& Kusnadi, J. 2018. Addition effect of red dragon fruit (Hylocereus polyrhizus) to antioxidant activity and physicochemical characteristic of Caspian Sea yoghurt. Jurnal Pangan dan Agroindustri 6(2): 13-22.

Moore, J.B., Horti, A. \& Fielding, B.A. 2018. Evaluation of the nutrient content of yogurts: A comprehensive survey of yogurt products in the major UK supermarkets. BMJ Open 8(8): e021387.

Muniandy, P., Shori, A.B. \& Baba, A.S. 2017. Comparison of the effect of green, white and black tea on Streptococcus thermophilus and Lactobacillus spp. in yogurt during refrigerated storage. Journal of the Association of Arab Universities for Basic and Applied Sciences 22: 26-30.

Muniandy, P., Shori, A.B. \& Baba, A.S. 2016. Influence of green, white and black tea addition on the antioxidant activity of probiotic yogurt during refrigerated storage. Food Packaging and Shelf Life 8: 1-8.

Najgebauer-Lejko, D. 2019. Characteristics of probiotic yoghurts supplemented with pu-erh tea infusion. Acta Scientiarum Polonorum Technologia Alimentaria 18(2): 153-161.

Najgebauer-Lejko, D., Zmudziński, D., Ptaszek, A. \& Socha, R. 2014. Textural properties of yogurts with green tea and puerh tea additive. International Journal of Food Science and Technology 49(4): 1149-1158.

Najgebauer-Lejko, D., Sady, M., Grega, T. \& Walczycka, M. 2011. The impact of tea supplementation on microflora, $\mathrm{pH}$ and antioxidant capacity of yoghurt. International Dairy Journal 21(8): 568-574.

Nikniaz, Z., Mahdavi, R., Ghaemmaghami, S.J., Yagin, N.L. \& Nikniaz, L. 2016. Effect of different brewing times on antioxidant activity and polyphenol content of loosely packed and bagged black teas (Camellia sinensis L.). Avicenna Journal of Phytomedicine 6(3): 313-321.

Ochanda, S.O., Wanyoko, J.K., Faraj, A.K., Onyango, C.A. \& Ruto, H.K. 2015. Effects of tea (Camellia sinensis) phytochemicals on the yoghurt cultures (Lactobacillus bulgaricus and Streptococcus thermophilus) during development and storage of tea fortified yoghurts. Journal of Food Research 4(4): 59.
Owuor, P.O. \& Obanda, M. 2001. Comparative responses in plain black tea quality parameters of different tea clones to fermentation temperature and duration. Food Chemistry 72(3): 319-327.

Phadungath, C. 2005. The mechanism and properties of acidcoagulated milk gels. Songklanakarin Journal of Science and Technology 27(2): 433-448.

Prawira-Atmaja, M.I. \& Rohdiana, D. 2018. Diversifikasi produk berbasis teh pada industri pangan, farmasi, dan kosmetik. Perspektif 17(2): 150-165.

Sah, B.N.P., Vasiljevic, T., McKechnie, S. \& Donkor, O.N. 2016. Physicochemical, textural and rheological properties of probiotic yogurt fortified with fibre-rich pineapple peel powder during refrigerated storage. $L W T$ - Food Science and Technology 65: 978-986.

Shokery, E.S., Ziney, M.G.E., Yossef, A.H. \& Mashaly, R.I. 2017. Effect of green tea and moringa leave extracts fortification on the physicochemical, rheological, sensory and antioxidant properties of set-type yoghurt. Advances in Dairy Research 5(2): $1-10$.

Singh, B.N., Rawat, P.A.K.S., Bhagat, R.M. \& Singh, B.R. 2015. Black Tea: Phytochemicals, cancer chemoprevention and clinical studies. Critical Reviews in Food Science and Nutrition 57(7): 1394-1410.

Smith, A., Maben, A. \& Brockman, P. 1994. Effects of evening meals and caffeine on cognitive performance, mood and cardiovascular functioning. Appetite 22(1): 57-65.

Tan, G. \& Korel, F. 2007. Quality of flavored yogurt containing added coffee and sugar. Journal of Food Quality 30(3): 342-356.

Uchida, K., Akashi, K., Motoshima, H., Urashima, T., Arai, I. \& Saito, T. 2009. Microbiota analysis of Caspian Sea yogurt, a ropy fermented milk circulated in Japan. Animal Science Journal 80(2): 187-192.

Uchiyama, Y., Yamashita, M., Kato, M., Suzuki, T., Omori, M. \& Chen, R. 2011. Evaluation of the taste of tea with different degrees of fermentation using a taste sensing system. Sensors and Materials 23(8): 501-506.

Ünal, G., Cem, K., Özer, K., Ecem, A. \& Sibel, A.A. 2018. Effect of supplementation with green and black tea on microbiological characteristics, antimicrobial and antioxidant activities of drinking yoghurt. Journal of Agricultural Science 24(2): 153-161.

Ünal, G., Cem, K., Özer, K., Ecem, A. \& Sibel, A.A. 2016. Influence of supplementation with green and black tea on viscosity and sensory characteristics of drinking yoghurt. Journal of Agriculture Faculty of Ege University 53(3): 343-349.

Vaningelgem, F., Zamfir, M., Adriany, T. \& Vuyst, L.D. 2004. Fermentation conditions affecting the bacterial growth and exopolysaccharide production by Streptococcus thermophilus ST 111 in milk-based medium. Journal of Applied Microbiology 97(6): 1257-1273.

Yang, Z., Baldermann, S. \& Watanabe, N. 2013. Recent studies of the volatile compounds in tea. Food Research International 53(2): 585-599.

Zhang, L., Ho, C.T., Zhou, J., Santos, J.S., Armstrong, L. \& Granato, D. 2019. Chemistry and biological activities of 
processed Camellia sinensis teas: A comprehensive review. Comprehensive Reviews in Food Science and Food Safety 18(5): 1474-1495.

Zhang, Q.W., Lin, L.G. \& Ye, W.C. 2018. Techniques for extraction and isolation of natural products: A comprehensive review. Chinese Medicine 13(1): 1-26.

Shinta Maharani*, Nanda Anggita Sari \& Anita Rahayu Department of Agroindustrial Technology of Education Faculty Technological and Vocational Education Universitas Pendidikan Indonesia

Bandung, West Java

Indonesia

M Iqbal Prawira-Atmaja

Department Postharvest \& Engineering

Research Institute for Tea and Cinchona

Gambung, Kab. Bandung, West Java

Indonesia
Ana A

Department of Family Welfare Education

Faculty Technological and Vocational Education

Universitas Pendidikan Indonesia

Bandung, West Java

Indonesia

*Corresponding author; email: shinta.maharani@upi.edu

Received: 6 August 2020

Accepted: 23 August 2020 